\title{
The Determinants of Net Interest Margin: An Empirical Study of Indonesia Category-IV Banks for the Period of 2014- 2017
}

\author{
CHANDRA SETIAWAN ${ }^{1}$, NI MADE MAYLANANDA MAHARANI WISNA ${ }^{2}$ \\ ${ }^{1}$ Management Study Program Faculty of Business, PRESIDENT UNIVERSITY, INDONESIA, \\ E-mail: chandra@president.ac.id (corresponding author) \\ ${ }^{2}$ Management Study Program Faculty of Business, PRESIDENT UNIVERSITY, INDONESIA, \\ E-mail: maylanandamaharani@gmail.com
}

\begin{abstract}
Bank's Net Interest Margin (NIM) is a key indicator on how bank performs its intermediary function and necessary for the financial system stability. NIM is influenced by both internal and external determinants. This study aims to analyze these internal and external determinants of NIM for Indonesia's Category-IV banks in the period of 2014 to 2017. The internal determinants used as independent variables are Loan to Deposit Ratio (LDR), Operating Efficiency Ratio (OER), and Capital Adequacy Ratio (CAR). Meanwhile, the external determinants used as independent variables are Interest Rate volatility and Inflation. This study uses four Indonesia's Category-IV banks which were chosen by purposive sampling methodology based on criteria set with quarterly time horizon. These 4 commercial banks are those listed as 'Category-IV' or BUKU 4 during the study's time frame. The statistical approach being used is panel least square fixed effect model. This study reveals that Loan to Deposit Ratio (LDR), Operating Efficiency Ratio (OER), and Inflation have positive significant influence toward NIM. In contrast, Capital Adequacy Ratio (CAR) shows negative significant influence, while Interest Rate volatility contributes insignificantly to NIM. The overall findings underlined that contribution of internal factors are consistent in influencing the value of NIM in a significant way.
\end{abstract}

Keywords: Net Interest Margin; Bank Efficiency; Commercial Banks; Interest Rate Volatility; Inflation.

JEL Classification: G21, E50, C23 


\title{
Los Determinantes del Margen de Interés Neto: Un Estudio Empírico de los Bancos de Categoría IV de Indonesia para el Período 2014-2017
}

\author{
CHANDRA SETIAWAN ${ }^{1}$, NI MADE MAYLANANDA MAHARANI WISNA ${ }^{2}$ \\ ${ }^{1}$ Management Study Program Faculty of Business, PRESIDENT UNIVERSITY, INDONESIA, \\ E-mail: chandra@president.ac.id (corresponding author) \\ ${ }^{2}$ Management Study Program Faculty of Business, PRESIDENT UNIVERSITY, INDONESIA, \\ E-mail: maylanandamaharani@gmail.com
}

\begin{abstract}
RESUMEN
El Margen de Interés Neto (NIM) de los bancos es un indicador clave de cómo los bancos desempeñan su función de intermediación y es necesario para la estabilidad del sistema financiero. El margen de interés neto está influido por factores internos y externos. Este estudio tiene como objetivo analizar estos determinantes internos y externos del MNI para los bancos de categoría IV de Indonesia en el período de 2014 a 2017. Los determinantes internos utilizados como variables independientes son la relación entre préstamos y depósitos (LDR), la relación de eficiencia operativa (OER) y la relación de adecuación del capital (CAR). Mientras tanto, los determinantes externos utilizados como variables independientes son la volatilidad de los tipos de interés y la inflación. Este estudio utiliza cuatro bancos indonesios de categoría IV que fueron elegidos mediante una metodología de muestreo intencional basada en criterios establecidos con un horizonte temporal trimestral. Estos cuatro bancos comerciales son los que figuran en la "categoría IV" o BUKU 4 durante el período de estudio. El enfoque estadístico utilizado es el modelo de efectos fijos de mínimos cuadrados del panel. Este estudio revela que la relación entre préstamos y depósitos (LDR), la relación de eficiencia operativa (OER) y la inflación tienen una influencia positiva y significativa en el NIM. Por el contrario, el Ratio de Adecuación del Capital (RAC) muestra una influencia significativa negativa, mientras que la volatilidad de los tipos de interés contribuye de forma insignificante al MNE. Los resultados generales subrayan que la contribución de los factores internos influye de forma significativa en el valor del MNE.
\end{abstract}

Palabras clave: Margen de Interés Neto; Eficiencia Bancaria; Bancos Comerciales; Volatilidad de los Tipos de Interés; Inflación.

Clasificación JEL: G21, E50, C23

Recibido: 05 de Junio de 2021

Aceptado: 02 de Octubre de 2021 


\section{Introduction}

The whole economic system consists of numerous sectors such as financial system and sector. Financial system stability holds a very crucial role within a country's economic condition to maintain sustainable economy. As a sub-system of economic system, it has a function to allocate the funds from surplus parties to the deficit parties. An unstable and inefficient financial system can hamper the economic growth (Bank Indonesia, 2018).

Referring to Indonesia's Financial System Statistic data by Bank Indonesia, banking as financial institution is still dominating the financial service sector. It is indicated by the number of banking industry's total assets per December 2017 which is amounted up to $77.28 \%$ of the whole financial sector total assets, while the non-banking institution contributes only $22.72 \%$ within the same period (Bank Indonesia, 2018). In addition, according to Indonesia Banking Statistics 2017, commercial banks are still the largest fund channeling institution in Indonesia. The data show that $98.07 \%$ of fund disbursement is carried out by commercial banks, while $1.66 \%$ by rural banks, and $0.27 \%$ through Bank Indonesia Certificate (SBI) and Bank Indonesia Sharia Certificate (SBIS). Furthermore, for more specific, the commercial banks' market share is dominated by Category-IV banks in which during 2014 to 2017, their market share is valued within 45\%-52\% (OJK, 2017).

Indonesia's economic development is definitely relying toward the development and contribution of the banking sector. This is mainly driven by the fact that the role of banking as financial institution is needed to finance existing economic development (Sulistiyani, Gama, \& Astiti, 2019). According to Bank Indonesia, in the condition when banks are able to run their financial intermediation function in an efficient way, they will support and boost the economic growth of a country (Bank Indonesia, 2018). In line with this, there are findings that support and believe that in developing countries where the condition of the financial sector is dominated by banking, the acceleration of economic growth is highly dependent on how effective and efficient the functioning of the banking sector is (Jima, 2017). The context of bank's ability in performing the intermediation function can be proxied using Net Interest Margin (NIM) ratio. Referring to Table 1 below, the average of Net Interest Margin (NIM) of banks in Indonesia is comparatively higher compared to other ASEAN countries (ranked Top 2 during 2014 to 2017).

Table 1 Available Published ASEAN Bank NIM 2013-2017 (in \%)

\begin{tabular}{|c|c|c|c|c|}
\hline & 2012 & 2013 & 2014 & 2015 \\
\hline Brunei Darussalam & $5,66 \%$ & $5,15 \%$ & $5,49 \%$ & $4,24 \%$ \\
\hline Cambodia & $5,18 \%$ & $5,05 \%$ & $7,10 \%$ & $5,92 \%$ \\
\hline Indonesia & $5,49 \%$ & 4,89 & $4,23 \%$ & $5,39 \%$ \\
\hline Malaysia & $2,89 \%$ & $2,59 \%$ & $1,99 \%$ & $1,72 \%$ \\
\hline Myanmar & $4,07 \%$ & - & $0,67 \%$ & $1,59 \%$ \\
\hline Philippines & $3,49 \%$ & $3,24 \%$ & $3,70 \%$ & 3,58 \\
\hline Singapore & $1,65 \%$ & $1,59 \%$ & $1,74 \%$ & $1,59 \%$ \\
\hline Thailand & $2,94 \%$ & $2,80 \%$ & $3,26 \%$ & $3,07 \%$ \\
\hline Vietnam & $3,62 \%$ & $3,07 \%$ & $2,86 \%$ & $2,93 \%$ \\
\hline
\end{tabular}

To be more specific, the NIM of Category-IV banks in fact shows an incline and holds the highest NIM compared to other categories of conventional commercial banks in Indonesia. Referring to the following figure Initial growth throughout 2014 allowed Category-IV banks to have prominent NIM in 2015 and remain high until 2017. The fact that Category-IV banks dominate the market share of 
Indonesian commercial banks around $50 \%$ and how they started to make a significant increase in NIM starting in $\mathbf{2 0 1 4}$ led the researcher to use Category IV banks as the research sample. Moreover, it turned out that not only 2014 can be used as the initial year of research studies, but can also be continued to the next 3 years when Category IV banks appeared as the highest NIM holders.

Figure 1 Indonesian Commercial Banks' NIM 2014-2017

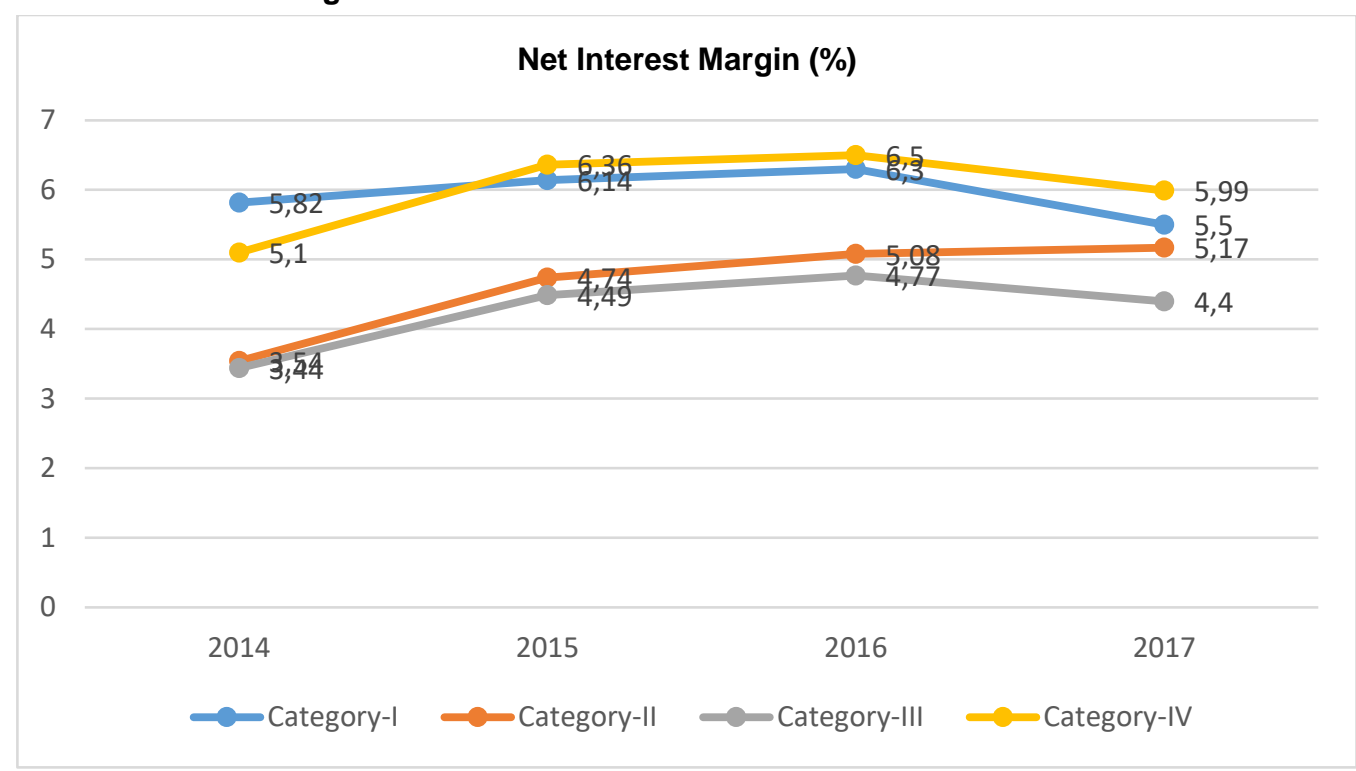

Source: Indonesia Banking Statistics 2017 (OJK)

High NIM is likely associated to the existence of bank inefficiency, especially in developing countries. It is underlined by a main reason that banks attempt to cut the costs by acquiring assets through high interest income, so technically the managerial expenses will be transferred to the bank's customers resulting in high interest rate charged and higher margin (Doyran, 2013). This statement is in line with the effort taken by Indonesia's Financial Services Authority (OJK) together with Bank Indonesia. Banking authorities in Indonesia have been trying to encourage commercial banks to lower NIM and loan interest rates at a reasonable level (OJK, 2016). Net Interest Margin is a proxy that can be used to represent both profitability and efficiency. Therefore, the interpretation toward high value of NIM would be variety. This could represent better income collected by banks through better lending practices in disbursing loans or tend to reflect lower levels of bank efficiency.

The fact through the data from Indonesia Banking Statistics (2017) shows the majority incline of Indonesia' Operating Efficiency Ratio from 2014 to 2017 was reflected by Operating Expense to Operating Income ratio where this condition further reflects the incline of inefficiency. In 2014, the ratio was $76.29 \%, 2015$ at $81.49 \%, 2016$ at $82.22 \%$, and 2017 at $78.64 \%$. The major market-share holder (Category-IV banks) stands as the group of banks with better efficiency compared to other groups in Indonesia. However, even though Category-IV is the most efficient group with these numbers below, it is still less efficient compared to other ASEAN neighbors. Cost to income ratio differs widely among ASEAN's banking industry. As in 2015, Indonesia's ratio was much higher than the average cost to income ratio in ASEAN, which was only around 40-60\% (The Habibie Center, 2015).

Table 2 Indonesian Commercial Banks OER 2014 - 2017

\begin{tabular}{|c|c|c|c|c|}
\hline & $\mathbf{2 0 1 4}$ & $\mathbf{2 0 1 5}$ & $\mathbf{2 0 1 6}$ & $\mathbf{2 0 1 7}$ \\
\hline Category-I & $85.26 \%$ & $85.86 \%$ & $88.09 \%$ & $87.31 \%$ \\
\hline Category-II & $81.04 \%$ & $85.48 \%$ & $85.38 \%$ & $86.40 \%$ \\
\hline Category-III & $84.67 \%$ & $90.71 \%$ & $89.33 \%$ & $86.07 \%$ \\
\hline Category-IV & $67.10 \%$ & $70.46 \%$ & $75.05 \%$ & $70.31 \%$ \\
\hline
\end{tabular}


This finding leads researchers to utilize the Operating Efficiency Ratio variable to be examined regarding its relevance toward NIM to figure out the first research question on how these most efficient groups respond, among other things, to their NIM in the event of a change in cost efficiency. The other variables used were taken in accordance with the basic understanding of how banks are actually modeled as dealers with risk averse characteristics facing asymmetric loan markets and thirdparty funds markets that are exposed to interest rate volatility in the money market (Williams, 2007).

Therefore, the researchers utilize Capital Adequacy Ratio (CAR) to represent risk-averse of bank, Loan to Deposit Ratio (LDR) to represent banks that stand as intermediary for loan market and thirdparty fund market, and also examine Interest Rate volatility. Then, inflation rate variable is added to represent macroeconomic condition. Jorgensen and Apostolou (2013) figure out that macroeconomic factors are relevant to describe bank interest margin and inflation rate is the main macroeconomic determinants (Jorgensen \& Apostolou, 2013). This is in line with the notion that among numerous macroeconomic factors, inflation variable is the most relevant determinant of bank interest margin, especially in developing countries (Fofack, 2016).

In recent years, studies about Net Interest Margin have been widely studied by numerous academic and research professional parties across countries. The findings reveal inconsistent results due to different countries and banks samples driven by different factors. Furthermore, the study on the use of interest rate volatility variable is relatively less in Indonesia. This reflects gaps, so further research needs to be conducted.

In this study, the researchers use several common variables i.e., Loan to Deposit Ratio, Capital Adequacy Ratio, Operating Efficiency Ratio, and Inflation. The researchers decided to propose one less used variable in studies in Indonesia which is interest rate volatility to fill in the gap and come up with new finding. All the variables used are intended to answer the second research question regarding which one between internal and external determinants most sensitively influences NIM of these banks.

This study is structured with Section 1 discussing on the research background, section 2 literature review, Section 3 elaborating the research methodology, Section 4 discussing the empirical results, and Section 5 for conclusions.

\section{Literature Review}

\subsection{Net Interest Margin (NIM)}

NIM is a necessary indicator for banking sector' effectiveness. It reflects the cost of conducting intermediation as well as the healthiness of banking sector (S.S \& Raje, 2019). Research on NIM is one of the topics that is widely studied in the banking industry. Ho and Saunder's (1981) study serve as the pioneer in analyzing NIM by modelling bank as an institution with intermediary function among the loans and third-party fund market. This scheme is then known as a "dealer" model among the depositors and borrowers. The spread of deposit rates and the lending rates is described as the fee to serve the intermediation function under the condition of uncertainty of deposit supplies and loan demands (Louzis \& Vouldis, 2015). Ho and Saunders (1981) recognize these two basic understanding on how bank acts as a risk-averse institution and how bank is exposed by the uncertainty in the money market in a form of asymmetry between deposit supplies and demand of loans which leads to interest rate volatility. In the development, NIM determinants eventually comes up from bank characteristic, industry, and macroeconomic factors (Williams, 2007).

\subsection{Loan to Deposit Ratio (LDR)}

LDR reflects the liquidity concern of a bank in which the greater the ratio indicates the lower the capacity of bank liquidity (Raharjo, Hakim, Manurung, \& Maulana, 2014). Trade-off between liquidity and profitability leads to the condition where banks must provide liquid assets (idle funds) to maintain liquidity. On the other hand, these funds when used for lending will yield higher returns for bank as income generated from the interest income growth (Judisseno, 2005). In addition, the greater the ratio 
indicates higher loan channeling which is related to credit risk. Regarding credit risk, in conditions that cause credit risk to tend to decrease, bank income in the form of net interest margin will decreaseresulting in high cost of risk (Khalil \& Farooq, 2019). In a different point of view, less liquid agents are potential to earn greater income from their aggressive loan distribution (Kosmidou, 2008). In addition, Haque et al. (2016) revealed that LDR had a significant positive relation with the NIM ratio (Chowdhury, Siddiqua, \& Chowdury, 2016). The same output is found in Lestari et al.'s (2021) study, in which Loan to deposit ratio (LDR) performs a positive and significant influence toward NIM. This means that LDR incline will lead to the incline in NIM (Lestari, Chintia, \& Akbar, 2021).

\subsection{Operating Expense to Operating Income (Efficiency Ratio)}

This is one indicator that measures the level of management efficiency of a bank. The greater the value of OER, the lower the bank's operating efficiency. Banks with lower efficiency have higher NIMs because they are expected to transmit the costs of inefficiency to customers (Plakalovic \& Alihodzic, 2015). In conditions where banks cannot operate efficiently, which is reflected in higher operating costs, part of these high costs tends to be transmitted to customers. (Suu \& Luu, 2020). Furthermore, higher NIM in Argentine is associated with higher operating expense and inefficiency (Doyran, 2013). A study also managed to identify that Operating Expense to Operating Income ratio influences NIM in a positive and significant way (Manurung, Hutahayan, Deniswara, \& Kartika, 2020).

\subsection{Capital Adequacy Ratio (CAR)}

CAR is a measure of the adequacy of capital owned by a bank used to compensate for the overall prospective risk attached to its earning assets which is calculated by dividing total capital by total riskweighted assets. (Raharjo, Hakim, Manurung, \& Maulana, 2014). In other words, CAR represents ratio that functions to accommodate losses regarding bank's risk existence (Sulistiyani, Gama, \& Astiti, 2019). Bank is recognized to have better ability in bearing credit risk or any productive asset if they have better or higher CAR (Syukriah, Maharani, \& Putri, 2020)

According to risk-aversion model, the higher the risk-aversion level of a bank, the higher margin set by them as the nature of bank which avoid the risk (Williams, 2007). This is in line with study that reveals the fact that capital is positively related to NIM, which reflects the importance of equity scale in increasing the NIM of their sample banks. (An \& Loan, 2016).

Meanwhile, Akinlo and Owayemi (2012) stated that capital adequacy contributes negative relation on bank interest margin (Akinlo \& Owoyemi, 2012). Horvath (2009) also stated when a bank is having greater capital adequacy, it is likely to be connected to smaller value of interest margins (Horvath, 2009). Brock and Franken as cited in Horvath (2009) claimed the motivation to be attached on higher risk is coming from less-capitalized banks as they expect to generate higher return as the compensation (Brock \& Franken M., 2003). Thus, less-capitalized bank claimed to be relevant with higher margin. Ahokpossi (2013) also adds that well-capitalized banks can handle lower borrowing costs as well as lower bankruptcy risk which leads to the creation of lower margins. (Ahokpossi, 2013).

\subsection{Interest Rate Volatility}

The interest rate of money market is also a relevant driver of NIM (Angori, Aristei, \& Gallo, 2019). Bank in serving as an intermediary function deal with asymmetry and uncertainty in the supply of deposit and demand of loan. Thus, when the mismatch occurs, bank will cope the mismatch by dealing with the money market, which is exposed to the uncertainty and risk (Williams, 2007).

According to Ho and Saunder (1981) which was then developed by McShane and Sharpe (1985), regarding money market interest rate volatility, this variable should give a positive sign result toward the NIM. This positive sign means that within a ceteris paribus condition, greater volatility represents a greater risk and uncertainty faced in the money market. This means that greater intermediation margin is required to compensate the risk (Cruz-Garcia, 2017). Money market rate volatility will lead banks to increase NIM caused by higher market risk (Angori, Aristei, \& Gallo, 2019). A study found that 
a positive sign definitely exists to represent the relation of interest rate volatility and NIM, but insignificant relation occurs in the sample they observed. This is justified as a result of sample uniqueness or characteristics (Afzal \& Mirza, 2010). In Indonesia, interbank interest rates represent conditions in the money market. The money market serves as the first transmission of the monetary policy rate which will ultimately affect third party funds, the bank credit market, and the NIM value. However, the interbank rate transmission process to influence bank interest rates generally does not occur instantaneously, but there is a time lag due to the bank's internal factors (Warjiyo, 2004). Hijazeen (2017) also reveals an insignificant relation, but with a negative relation. In their study, interest rate volatility is measured by a standard deviation of interbank interest rate. The insignificant negative result can be explained as a condition that captures the fact of conservative behavior of Jordanian commercial banks as they tend to encourage depositors by raising deposit rates and limiting appetite for lending. Thus, this results in a decrease in NIM. Furthermore, the statistically insignificant result reflects that bank do not offset these payments by having higher NIM (Hijazeen, 2017).

\subsection{Inflation Rate}

Inflation rate is considered as one of macroeconomic variables which has been used in numerous banking research including in the study regarding bank interest margin. Inflation is one of the essential factors in a country's economic condition. A fluctuating Inflation condition is potential to lead into an economic instability (Ramadhani \& Nugroho, 2019). Jorgensen and Apostolou (2013) identify that macroeconomic factors are relevant to describe bank interest margin and inflation rate is the main macroeconomic determinants (Jorgensen \& Apostolou, 2013). This is in line with Fofack who stated that among numerous macroeconomic factors, inflation variable is the most relevant determinant of bank interest margin, especially in developing countries (Fofack, 2016). Perry (1992) as cited in Tarus et al. (2012) stated that the influence of inflation toward Net Interest Margin depends on whether or not the inflation is anticipated (Tarus, Chekol, \& Mutwol, 2012). Under the condition of anticipated inflation, bank parties are able to adjust the interest rate directly to increase the value of NIM. Meanwhile, a non- anticipated inflation leads to the lower margin as banks might take longer time in adjusting the interest rate. Hence, it affects NIM negatively due to the additional cost incurred under the condition of inflation. Under the elevated inflation period, debtors or borrowers with high risk profile-those who are most likely attached to loans default-are entering the market (Doyran, 2013).

\section{Research Method}

\subsection{Sampling and Data Collection Method}

This study implements the quantitative approach, which is a research method that gathers data in form of numerical data. The quantitative model applies deductive process which means the development of the hypotheses refer to the theory to define how each independent variable influences the dependent variable. Hypotheses decision regarding the rejection or acceptance will be underlined by the result of the data from the hypotheses testing (Sekaran \& Bougie, 2013)

The sampling is using the non-probability sampling method, which is the purposive sampling. It is explained as a sampling method that utilizes people's own judgement to choose the sample (Greener, 2008). The sample's criteria were commercial banks listed as Indonesia's Category-IV during the period observed (2014 - 2017) and fully published their quartal report. With these criteria, researchers obtain 4 banks as observation samples, i.e., PT Bank Central Asia Tbk., PT Bank Mandiri Tbk., PT Bank Negara Indonesia Tbk., and PT Bank Rakyat Indonesia Tbk. This study utilizes secondary data which is collected from respective bank quartal report, Bank Indonesia, Financial Service Authority (OJK), and Statistics Indonesia (BPS).

\subsection{Research Instrument}

The main analysis tool used in this research is Eviews (Econometric Views) version 9. This study uses Eviews to process the raw data statistically in order to get result to be interpreted. Eviews is a software 
which functions as data analysis platform and perform regression analysis on statistical data (Eviews, 2017).

\subsection{Explaining Model of Study}

This study combines both time series and cross-section, so the researchers used data type which can accommodate this, i.e., panel data. On the lesser extent, panel data have both space and time dimensions. Panel data approach implemented within this study is the balanced panel data in which the number of observations for both time series and cross-section units are the same (Gujarati, 2003). Time series in this study covers the period of 2014 to 2017 quarterly which are equal to 16 time-series data (four years' times by four quarter per year). Meanwhile, the number of cross-sections used is 4 . Therefore, there are $\mathbf{6 4}$ data as the number of observations used in this study.

There are three alternative estimation models for panel data, which are: 1) Common Constant Model, 2) Fixed Effect Model, and 3) Random Effect Model. To decide one, Chow and Hausman test was run. Chow test was done to decide between common effect or fixed effect model (Basuki \& Prawoto, 2016). Statistical result shows the probability of the chi-square was valued less than 0.05 which was 0.000 . Therefore, the Fixed Effect model was chosen. Afterwards, the Hausman test was performed to select whether Fixed effect or Common Effect model is the most suitable one. However, due to the number of cross sections within this study were less than the independent variables, Hausman test was ignored and Fixed Effect Model was deliberately selected (Gujarati, 2003). Therefore, Fixed Effect Model was the most suitable model for the panel regression in this study.

Under panel least square fixed effect model, multiple regression analysis was run once all classical assumption tests had been fulfilled. Below is the equation form of the multiple regression analysis utilized within this study:

$$
\mathrm{NIM}=\alpha+\beta_{1} \mathrm{LDR}_{\mathrm{it}}+\beta_{2} \mathrm{CAR}_{\mathrm{it}}+\beta_{3} \mathrm{OER}_{\mathrm{it}}+\beta_{4} \text { INTVOL }_{i t}+\beta_{5} \text { INFrate }_{i t}+\mathrm{e}_{\mathrm{it}}
$$

$\begin{array}{ll}\text { NIM } & : \text { Net Interest Margin } \\ \text { LDR } & : \text { Loan to Deposit Ratio } \\ \text { CAR } & : \text { Capital Adequacy Ratio } \\ \text { OER } & : \text { Operating Efficiency Ratio } \\ \text { INTVOL } & : \text { Interest Rate Volatility } \\ \text { INFrate } & : \text { Inflation Rate (QtQ) } \\ \beta_{1}, \beta_{2}, \ldots, & \beta_{\mathrm{i}}: \text { Regression Coefficient } \\ \alpha & : \text { Constanta, as the value of } Y \text { when all } X \text { equals to zero. } \\ \mathrm{e} & : \text { standard error } \\ \mathrm{i} & : \text { number banks in total } \\ \mathrm{t} & : \text { number observations for each bank in total }\end{array}$

\subsubsection{Estimation of the Determinants of Net Interest Margin}

In this study, the variables are divided into two types based on their relationship, which are the dependent variable represented by Net Interest Margin $(Y)$ and the independent variables represented by Loan to Deposit Ratio (X1), Operating Efficiency Ratio (X2), Capital Adequacy Ratio (X3), Interest Rate volatility (X4), and Inflation Rate (X5). The researchers aim to see any partial influence from each independent variable toward dependent variable. Accordingly, the simultaneous influence from all independent variables. Under multiple regression analysis, T-test is conducted to investigate the partial influence of each independent variable by measuring its value of significance. Meanwhile, Ftest is applied to check the simultaneous influence toward the dependent variable. In addition, the adjusted $R$ square is recognized to identify the value of the independent variables' variation in explaining the dependent variable. 
The type and definition of each variable used in this study can be completely seen in the following Table.

Table 3 Explanatory Research Variables

\begin{tabular}{|c|c|}
\hline VARIABLE & INDICATOR \\
\hline Net Interest Margin (NIM) & $\begin{array}{l}=\frac{\text { Annualized Net Interest Income }}{\text { Average Earning Assets }} \\
\text { Measurement: in \% } \\
\text { Source(s): Given ratio in published Bank Report. Due to } \\
\text { limitation on calculating average earning assets manually. }\end{array}$ \\
\hline Loan to Deposit Ratio (LDR) & $\begin{array}{l}=\frac{\text { Total Loans }}{\text { Total ThirdParties Funds }} \\
\text { Measurement: in } \% \\
\text { Source(s): Calculated from the above, calculation } \\
\text { component was taken from published bank report. }\end{array}$ \\
\hline $\begin{array}{l}\text { Operating Efficiency Ratio } \\
\text { (OER) }\end{array}$ & $\begin{array}{l}=\frac{\text { Operating Expense }}{\text { Operating Income }} \\
\text { Measurement: in \% } \\
\text { Source }(\mathrm{s}): \text { Calculated from the above, calculation } \\
\text { component was taken from published bank report }\end{array}$ \\
\hline $\begin{array}{l}\text { Capital Adequacy Ratio } \\
\text { (CAR) }\end{array}$ & $\begin{array}{l}=\frac{\text { Total Capital }}{\text { Total Risk Weighted Assets }} \\
\text { Measurement: in } \% \\
\text { Source(s): Calculated from the above, calculation } \\
\text { component was taken from published bank report }\end{array}$ \\
\hline Interest Rate Volatility & $\begin{array}{l}\text { Standard deviation of monthly Interbank rate (3 months } \\
\text { maturities) data within intended quarter. } \\
\text { Measurement: in \% } \\
\text { Data Source(s): SEKI BI }\end{array}$ \\
\hline Inflation Rate (QtQ) & $\begin{array}{l}\text { Sum of the monthly Inflation rate within the respective } \\
\text { quartal period } \\
\text { Monthly inflation }=\frac{C P I(m)-C P I(m-1)}{C P I(m-1)} \times 100 \% . \\
\text { Measurement: in \% } \\
\text { Data Source(s): bps.go.id }\end{array}$ \\
\hline
\end{tabular}

\section{Results and Discussion}

\subsection{Descriptive Statistics}

The table below shows the detail descriptive statistics result of each variable. 
Table 4 Descriptive Statistic Result $(\mathrm{N}=64)$

\begin{tabular}{|l|c|c|c|c|}
\hline & Minimum & Maximum & Mean & Std. Deviation \\
\hline Net Interest Margin & 5.410 & 9.060 & 6.693 & 1.009 \\
\hline Loan to Deposit Ratio & 75.400 & 94.000 & 85.169 & 5.086 \\
\hline Operating Efficiency Ratio & 58.650 & 87.410 & 69.143 & 5.483 \\
\hline Capital Adequacy Ratio & 15.570 & 23.620 & 19.463 & 2.163 \\
\hline Interest Rate Volatility & 0.000 & 0.880 & 0.238 & 0.269 \\
\hline Inflation Rate & -0.430 & 4.430 & 1.121 & 0.997 \\
\hline
\end{tabular}

\subsection{Multiple Regression Analysis}

Prior to multiple regression analysis, classical assumption test should be fulfilled. It covers the test of normality, multi-collinearity, heteroscedasticity, and autocorrelation where all the classical assumption tests to support this study have been fulfilled. Then, the chosen independent variables were processed by Eviews 9 using the Fixed Effect Model of panel data regression.

Figure 2 Multiple Regression Analysis Result

\begin{tabular}{|c|c|c|c|c|}
\hline \multicolumn{5}{|c|}{ Dependent Variable: Y_NIM } \\
\hline \multicolumn{5}{|c|}{ Method: Panel Least Squares } \\
\hline \multicolumn{5}{|c|}{ Sample: 2014Q1 2017Q4 } \\
\hline \multicolumn{5}{|c|}{ Periods included: 16} \\
\hline \multicolumn{5}{|c|}{ Cross-sections included: 4} \\
\hline \multicolumn{5}{|c|}{ Total panel (balanced) observations: 64} \\
\hline \multicolumn{5}{|c|}{ White cross-section standard errors \& covariance (d.f. corrected) } \\
\hline Variable & Coefficient & Std. Error & t-Statistic & Prob. \\
\hline X1_LDR & 0.043787 & 0.016099 & 2.719854 & 0.0087 \\
\hline X2_OER & 0.020757 & 0.008266 & 2.511230 & 0.0150 \\
\hline X3_CAR & -0.061897 & 0.024009 & -2.578106 & 0.0126 \\
\hline X4_INTVOL & 0.031131 & 0.183809 & 0.169364 & 0.8661 \\
\hline X5_INFLATION & 0.038317 & 0.014708 & 2.605239 & 0.0118 \\
\hline C & 2.682548 & 1.287861 & 2.082948 & 0.0419 \\
\hline \multicolumn{5}{|c|}{ Effects Specification } \\
\hline \multicolumn{5}{|c|}{ Cross-section fixed (dummy variables) } \\
\hline & & & & 6.6926 \\
\hline R-squared & 0.924085 & Mean de & endent var & 56 \\
\hline Adjusted R-squared & 0.913043 & S.D. dep & dent var & 04 \\
\hline S.E. of regression & 0.297451 & Akaike in & criterion & 66 \\
\hline Sum squared resid & 4.866242 & Schwarz & iterion & $\begin{array}{r}+61 \\
59\end{array}$ \\
\hline
\end{tabular}




\begin{tabular}{llllr} 
Log likelihood & -8.362111 & Hannan-Quinn criter. & 0.6621 \\
& & & 67 \\
F-statistic & 83.68717 & Durbin-Watson stat & 0.8308 \\
Prob(F-statistic) & 0.000000 & & 14 \\
\hline \hline
\end{tabular}

The resultis simplified in form of below equation:

\section{$Y=2.683+0.043 \times 1+0.020 \times 2-0.061 \times 3+0.031 \times 4+0.038 \times 5$}

\subsubsection{Loan to Deposit Ratio (LDR)}

It has probability value less than $0.05(0.009<0.05)$ and coefficient regression of 0.043 , which means Loan to Deposit Ratio has significant and positive influence toward Net Interest Margin. Under condition when LDR increases, the loan growth is greater compared to the growth of third-party funds. This leads to the increase in the net interest income of a bank due to the greater growth of interest revenue collected from loan growth. This is in line with the supporting theory from Kosmidou (2008) that less liquid agents are potential to earn greater income from their aggressive loan distribution (Kosmidou, 2008). In addition, the result is also in line with findings from Haque et al. (2016) and Lestari et al. (2021) that Loan to deposit ratio (LDR) has a positive and significant influence on NIM. This means that LDR incline will lead to the incline in NIM (Lestari, Chintia, \& Akbar, 2021).

\subsubsection{Operating Efficiency Ratio (OER)}

OER is reflected by operating expense to operating income ratio that has probability value of less than $0.05(0.015<0.05)$ and coefficient regression of 0.020 . This means that Operating Efficiency Ratio has a significant and positive influence on Net Interest Margin. This positive relationship shows the behavior of banks in transmitting operational cost inefficiencies to customers in the form of higher margins. This is done to compensate the larger costs incurred by the bank's operational activities. The result of this study is in line with previous finding from Doyran (2013) that higher NIM in Argentine is associated with higher operating expense and inefficiency (Doyran, 2013). Plakalovic and Alilodzic (2015) state that banks with lower efficiency (larger OER values) have higher NIMs because they are expected to transmit inefficiency costs that occur to customers (Plakalovic \& Alihodzic, 2015). Another study from Manurung et al. (2020) also supports this finding.

\subsubsection{Capital Adequacy Ratio (CAR)}

CAR has a probability value of less than $0.05(0.013<0.05)$ and coefficient regression of -0.061 , which means a significant and negative influence on NIM is confirmed. This negative and significant relation is supported by the findings from Akinlo and Owayemi (2012) and Horvath (2009). This finding is in line with Ahokpossi (2013) who stated that well-capitalized banks deal with lower borrowing cost as well as lower risk of bankruptcy. Well-capitalized banks have a stronger capital base to compensate for some of the risk so as not to only burden them with margin (Ahokpossi, 2013).

\subsubsection{Interest Rate volatility}

Interest Rate volatility has probability value of more than $0.05(0.866>0.05)$ and coefficient regression of 0.031 . This means that the insignificant and positive influence on Net Interest Margin is confirmed. This finding is in line with the results of Afzal (2010) and Islam \& Nishiyama (2016).

The process of transmitting policy rate to interbank rate to eventually influence bank interest rate generally does not take place immediately, but there is a time lag considering the bank's internal factors (Warjiyo, 2004). The researcher considers that for the sample of banks in Indonesia, this result is not significant because the volatility conditions are not directly responded to by the bank. Banks 
perhaps need more time to transmit the volatile interbank rate as a reference for them to set new margin. As a limitation of previous research studies with a sample of Indonesian banks that used interest rate volatility as one of the independent variables, the result of this study result appears as a new finding.

\subsubsection{Inflation Rate}

Inflation Rate has a probability value of less than $0.05(0.012<0.05)$ and coefficient regression of 0.038 , which means Inflation Rate has a significant and positive influence on NIM. The positive relationship that occurs with rising inflation can be anticipated by the bank, so that the bank will adjust the larger margin faster for the occurring cost inflation. This finding is in line with Gesang R et al. (2014) and Plakalovic and Alihodzic's (2015) studies.

\subsubsection{F-test result}

It can be said that Loan to Deposit Ratio, Operating Efficiency Ratio, Capital Adequacy Ratio, Interest Rate Volatility and Inflation Rate can explain the variation of NIM by $91.30 \%$, while the remaining $8.70 \%$ is influenced by other variables not examined in this study.

\section{Conclusion}

Net Interest Margin of Indonesia Category-IV Banks for the period of 2014 to 2017 was more sensitive to be influenced by bank internal factors. This answers the objective of this study to figure out which one between internal and external determinants is more impactful in influencing NIM. From the internal factors, all of the variables, i.e., Loan to Deposit Ratio, Operating Efficiency Ratio, Capital Adequacy Ratio contribute significant influence at 5\% significance level to NIM. Loan to Deposit Ratio and Operating Efficiency Ratio influence NIM positively, while the Capital Adequacy Ratio performs negative influence. Meanwhile, from the external factors, inflation rate is the only factor that significantly influences NIM with positive direction. Findings about the insignificant contribution of interest rate volatility for the sample in the quarterly period contribute as new findings.

This study also answers the objective of confirming that the group of banks with the highest NIM and better operational efficiency in Indonesia still engages in 'cost transmission' behavior. Referring to statistical result, operating expense to operating income ratio and NIM show a positive relation. This means that the greater operating expense results in greater NIM. Cost or expense is still managed to be transmitted to higher NIM. This is related to the possible behavior of banks in most developing countries according to previous studies and other related findings. Even though group of banks observed are banks with better efficiency among others, the researchers still suggest them to be able to manage costs because every increase in costs will be followed by an increase in NIM.

\section{References}

1. Afzal, A., \& Mirza, N. (2010). The Determinants of Interest Rate Spreads in Pakistan's Commercial Banking Sector. SSRN Electronic Journal. DOI: 10.2139/ssrn.1653875.

2. Ahokpossi, C. (2013). Determinants of Bank Interest Margins in Sub-Saharan Africa. IMF Working Paper African Department. DOI: http://dx.doi.org/10.5089/9781475551136.001, 1-19.

3. Akinlo, A. E., \& Owoyemi, B. O. (2012). The Determinants of Interest Rate Spreads in Nigeria: An Empirical Investigation. . Modern Economy. DOI: http://dx.doi.org/10.4236/me.2012.37107, 837845.

4. An, P. H., \& Loan, V. T. (2016). Factors affecting net interest margin of joint-stock commercial banks in Vietnam. Journal of Economic Development 24(1). DOI: 10.24311jabes2017.24.1.01, 92-103. 
5. Angori, G., Aristei, D., \& Gallo, M. (2019). Determinants of Banks' Net Interest Margin: Evidence from the Euro Area during the Crisis and Post-Crisis Period. Sustainability. DOI: 10.3390/su11143785.

6. Bank Indonesia. (2018). Stabilitas Sistem Keuangan. Retrieved from Bank Indonesia: https://www.bi.go.id/id/perbankan/ssk/ikhtisar/pentingnya/Contents/Default.aspx

7. Bank Indonesia. (2018). Statistik Sistem Keuangan Indonesia. Retrieved from Bank Indonesia: https://www.bi.go.id/id/statistik/sski/Pages/SSKI_Maret_2018.aspx

8. Basuki, A., \& Prawoto, N. (2016). Analisis Regresi Dalam Penelitian Ekonomi dan Bisnis: Dilengkapi Aplikasi SPSS \& Eviews. Jakarta: Rajawali Pers/Raja Grafindo Persada.

9. Brock, P., \& Franken M., H. (2003). Measuring the Determinants of Average and Marginal Bank Interest Rate Spreads in Chile, 1994-2001. Journal Economía Chilena (The Chilean Economy), Central Bank of Chile, vol. 6(3), 45-65.

10.Chowdhury, A. M., Siddiqua, A., \& Chowdury, A. M. (2016). Relationship between Liquidity Risk and Net Interest Margin of Conventional Banks in Bangladesh. Asian Business Review Vol 6 No 3. DOI: https://doi.org/10.18034/abr.v6i3.43, 175=178.

11.Cruz-Garcia, P. (2017). Interest Rates and Net Interest Margins: The Impact of Monetary Policy. The Business of Banking. DOI: 10.1007/978-3-319-54894-4_2, 5-33.

12.Doyran, M. A. (2013). Net Interest Margins and Firm Performance in Developing Countries: Evidence from Argentine Commercial Banks. Management Research Review, Vol. 36 Iss 7. DOI: http://dx.doi.org/10.1108/MRR-05-2012-0100, 720-742.

13.Fofack, A. D. (2016). The determinants of interest rate spread: Empirical evidence from the Central African economic and monetary community. Journal of Economics and International Finance Vol. 8 (6). DOI: 10.5897/JEIF2016.0759, 66-78.

14.Greener, S. (2008). Business Research Methods. Chicherster, West Sussex John Wiley \& Sons, Inc.

15.Gujarati, D. N. (2003). Basic Econometrics: Fourth Edition. United States: McGraw-Hill/Irwin.

16. Hijazeen, I. (2017). The Determinants of Net Interest Margins in the Jordanian Commercial Banks. International Journal of Business and Social Science Vol 8. Number 8, 27-37.

17. Horvath, R. (2009). The Determinants of the Interest Rate Margins of Czech Banks. Journal of Economics and Finance, 128-136. DOI: http://hdl.handle.net/10419/83401.

18.Islam, M. S., \& Nishiyama, S.-I. (2016). The determinants of bank net interest margins: A panel evidence from South Asian countries. Research in International Business and Finance. DOI: https://doi.org/10.1016/j.ribaf.2016.01.024, 501-514.

19.Jima, M. D. (2017). Determinants of Net Interest Margin in the Ethiopian Banking Industry. Journal of Finance and Economics, Vol. 5, No. 3 DOI:10.12691/jfe-5-3-2, 96-104.

20.Jorgensen, O. H., \& Apostolou, A. (2013). Brazil's Bank Spread in International Context From Macro to Micro Drivers. Policy Research Working Paper 6611. DOI: 10.1596/1813-9450-6611, 1-40.

21.Judisseno, R. K. (2005). Sistem Moneter dan Perbankan di Indonesia (Monetary System and Banking in Indonesia). Jakarta: Gramedia Pustaka Utama.

22.Khalil, A., \& Farooq, U. (2019). Determinants of Net Interest Margins in Emerging Markets: A Generalized Method of Moments Approach. Journal of Quantitative Methods 3(1) DOI: https://doi.org/10.29145/2019/jqm/030103, 38-55.

23.Kosmidou, K. (2008). The determinants of banks' profits in Greece during the period of EU financial integration. Journal of Managerial Finance Vol 34 Issue 3. DOI: https://doi.org/10.1108/03074350810848036, 146-159.

24.Lestari, H. S., Chintia, H., \& Akbar, I. C. (2021). Determinants of Net Interest Margin on Conventional Banking: Evidence in Indonesia Stock Exchange. Jurnal Keuangan dan Perbankan Vol 25 Issue 1 DOI: https://doi.org/10.26905/jkdp.v25i1.5102, 104-116. 
25.Louzis, D. P., \& Vouldis, A. T. (2015). Profitability in the Greek Banking System: A Dual Investigation of Net Interest and Non-Interest Income. Bank of Greece Working Paper, 1-48.

26.Manurung, A. H., Hutahayan, B., Deniswara, K., \& Kartika, T. R. (2020). Determinant of Net Interest Margin in Indonesia Bank Moderated by Risk. International Journal of Advanced Science and Technology, 11317-11328.

27.OJK. (2016, April). Perbankan: Berita dan Kegiatan. Retrieved from OJK: https://www.ojk.go.id/id/kanal/perbankan/berita-dan-kegiatan/siaranpers/Documents/Pages/Insentif_SukuBunga/No.\%20SP\%2034\%20DKNS\%200JK\%204\%202016.pd $f$

28.OJK. (2017). Statistik Perbankan Indonesia - Desember 2017. Retrieved from OJK (Otoritas Jasa Keuangan): https://www.ojk.go.id/id/kanal/perbankan/data-dan-statistik/statistik-perbankanindonesia/Pages/Statistik-Perbankan-Indonesia---Desember-2017.aspx

29.Plakalovic, N., \& Alihodzic, A. (2015). Determinants of the Net Interest Margins in BH Banks. Industrija, Vol.43 No 1. DOI: 10.5937/industrija43-7544, 133-153.

30.Raharjo, P. G., Hakim, D. B., Manurung, A. H., \& Maulana, T. N. (2014). The Determinant of Commercial Banks' Interest Margin in Indonesia: An Analysis of Fixed Effect Panel Regression. International Journal of Economics and Financial Issues, Vol. 4, No. 2, 295-308.

31.Ramadhani, R., \& Nugroho, W. (2019). Analysis of The Effect of Exchange Rates, E-Money and Interest Rates on The Amount of Money Supply and Its Implications on The Inflation Level in Indonesia 2012-2017 Period. International Journal of Accounting \& Finance in Asia Pacific (IJAFAP) Vol 2 No.1. DOI: https://doi.org/10.32535/ijafap.v2i1.364.

32.S.S, B., \& Raje, N. (2019). Net Interest Margins of Banks in India. The Journal of Applied Economic Research. Vol 13 Issue 2. https://doi.org/10.1177/0973801018812545, 192-207.

33.Sekaran, U., \& Bougie, R. (2013). Research Methods for Business - A Skill Building Approach 6th Edition. Chicherster, West Sussex John Wiley \& Sons, Inc.

34.Sulistiyani, N., Gama, A. W., \& Astiti, N. Y. (2019). Lending Growth Determinant on Rural Banks in Denpasar. International Journal of Accounting \& Finance in Asia Pacific Vol 2 No 2 . DOl: https://doi.org/10.32535/ijafap.v2i2.539, 1-12.

35.Suu, N. D., \& Luu, T.-Q. (2020). Net Interest Marginof Commercial Banks in Vietnam. Advances in Decision Sciences Volume 24 Issue 1. DOI: https://doi.org/10.47654/v24y2020i1p1-27.

36.Syukriah, S., Maharani, S. N., \& Putri, D. M. (2020). Analysis of the Capital Adequate Ratio (CAR), Non-Performing Loans (NPL), and Return on Assets (ROA) Effect on Credit Distribution of Commercial Banks Listed on the Indonesia Stock Exchange. International Journal of Accounting \& Finance in Asia Pasific (IJAFAP), Vol 3 No 2 2020. DOI: https://doi.org/10.32535/ijafap.v3i2.838, 9196.

37.Tarus, D. K., Chekol, Y. B., \& Mutwol, M. (2012). Determinants of Net Interest Margins of Commercial Banks in Kenya: A Panel Study. Procedia Economics and Finance 2, DOI: https://doi.org/10.1108/AJEMS-05-2017-0094, 199-208.

38.The Habibie Center. (2015). Banking Integration in ASEAN: Challenges and Issues Vol 2.Issue 5. Indonesia: The Habibie Center - ASEAN Studies Program.

39. Warjiyo, P. (2004). Mekanisme Transmisi Kebijakan Moneter di Indonesia. Jakarta: Bank Indonesia.

40.Williams, B. (2007). Factors Determining Net Interest Margins in Australia: Domestic and Foreign Banks. Journal compilation New York University Salomon Center, Financial Markets, Institutions V.16 No 3. DOI: https://doi.org/10.1111/j.1468-0416.2007.00122.x, 145-166. 